\title{
Female Constituency, Electoral Competition, and Local Maternity Policy in Korea
}

\author{
Doo-Rae Kim*
}

\begin{abstract}
This study explores the dynamic nature of maternity policy formation by focusing on the role of the female constituency and electoral competition in rendering policy makers, regardless of their gender, more receptive to the interests of women. The study utilizes original data on maternity policy benefits collected from local governments in Korea. The results show that a strong female constituency and intense electoral competition can lead local policy makers to establish greater maternity benefits. These findings suggest that the electoral power of women in the citizenry and the political vulnerability of elected officials constitute alternative channels for female influence on the formation of local maternity policy in Korea.
\end{abstract}

Keywords: gender, female constituency, electoral competition, maternity policy

\section{INTRODUCTION}

It has been widely accepted that female representation in policy-making institutions and bureaucratic agencies is the most important condition for the formulation and implementation of public policies that benefit female citizens. One strand of this representative government theory has examined the link between the gender of elite policy makers and legislative outcomes (Dolan \& Ford, 1995; Mansbridge, 1999; Swers, 2005). Legislative institutions with greater numbers of female lawmakers are expected to produce more woman-friendly policies. The other strand of the theory has

\footnotetext{
* Doo-Rae Kim is an associate professor in the Department of Public Administration at Korea University. E-mail: kimdr@korea.ac.kr. This work was supported by a grant from the National Research Foundation of Korea (NRF-2010-327-B00730). An earlier version of this manuscript was presented at the 2011 annual conference of the Midwest Political Science Association. The author would like to thank Hee-Kang Kim for helpful comments and SeokJun Jang for excellent research assistance.
}

Manuscript received June 8, 2012; out for review June 26, 2012; review completed August 20, 2012; accepted August 22, 2012.

The Korean Journal of Policy Studies, Vol. 27, No. 2 (2012), pp. 121-142.

(C) 2012 by the GSPA, Seoul National University 
focused on the effect of the gender makeup of bureaucratic organizations on policy implementation (Keiser, Wilkins, Meier, \& Holland, 2002; Meier \& Nicholson-Crotty, 2006). Bureaucratic agencies with greater numbers of female officials are expected to better serve the needs of female citizens. Furthermore, studies have found that the translation of female representation into women-friendly policy outcomes is contingent upon women's power within policy-making institutions (Swers, 2005), the salience of a policy issue to women's interests (Dolan, 2000), the feminist mission of an agency (Kelly \& Newman, 2001), and flexible organizational arrangements that allow bureaucratic discretion (Keiser et al., 2002).

There is no doubt that this gender-based theory of representative government has clarified important institutional conditions under which the interests of women can be promoted by female officeholders. Yet, the theory is still limited in the following respects. First, in focusing on the gender profile of government institutions, researchers tend to downplay the political role played by female citizens in the policy process. Especially in policy areas where beneficiaries are largely drawn from the female population, female constituency groups act to pressure elected officials (Allard, 2004; Dolan, 1997; Howard, 1992; Skocpol, 1995). Therefore, female representation in political inputs may also make a substantial difference in the extent to which elected officials act for female interests in the policy process.

Second, the gender-based theory of representative government has sidelined the important question of when policy makers, regardless of their gender, become more receptive to female interests. This weakness becomes evident as we critically examine the premise that the gender of a policy maker is the principal determinant of his or her positions on matters that directly affect female interests. Contrary to the conception of a gender divide in public decisions, support for female interests can differ not only across genders but also among individuals of the same gender due to factors that cross-cut the gender divide, such as political predisposition, race, and class (Mouffe, 1995; Pateman, 1989). Because not all male officials are less sympathetic than their female counterparts to the interests of women, the question of what motivates policy makers to take a favorable position on gendered issues warrants more cautious examination.

To add to our knowledge about causal links between gender representation and policy outputs, this study examines some alternative mechanisms of female influence in the policy process: the strength of female constituency and the electoral incentives of government officials. First, when policy benefits are disproportionately concentrated on the female population, female constituency groups are likely to form and exert a significant influence on decisions by elected policy makers. Second, when a highly contested election is anticipated, the incumbent policy makers may weigh female 
votes to enhance their chance of electoral success. These channels of female influence are not dependent on the gender of policy makers, but they can constrain the decisions of both male and female officials.

These theoretical possibilities can be adequately tested in policy areas that are closely related to women's interests. Previous research has identified a range of such policy areas, including education, children and family, health care, and social welfare (Herrnson, Lay, \& Stokes, 2003; Shapiro \& Mahajan, 1986; Swers, 2005). In this regard, the case of maternity support programs in Korea provides a good opportunity to examine whether gender diversity in policy-making institutions, strength of the female constituency, or electoral competition can advance female policy interests. Maternity policies can be considered as one of the compassion issues on which a gender gap in attitudes among both the mass public and elite politicians is most evident (Shapiro \& Mahajan, 1986; Swers, 2005).

Maternity support policies have been adopted to address public concern about drastically declining fertility in Korea. Local government policy makers perceived the seriousness of declining local populations earlier than did national government officials. During the era of rapid economic development in the 1980s, the younger generation's migration to urban areas and declining marriage rates and fertility gradually undermined the socioeconomic sustainability of rural communities (Kim, 1988; Lee \& Farber, 1985). As a result, local governments formulated and implemented policies to promote maternity before the national government did.

In this paper, I attempt to explain local-to-local variation in maternity benefits by focusing on some alternative channels of female influence in the policy process. The study is organized as follows. The next section briefly describes the local maternity policy context in Korea. In the theory section, we discuss competing explanations of the dynamic process by which various political and socioeconomic factors shape local maternity policies. Then, empirical analysis is performed with original data on maternity benefits collected from all 230 local governments in Korea. Finally, the findings are presented and larger implications are discussed.

\section{LOCAL MATERNITY POLICY IN KOREA}

Korea has seen drastically declining fertility over the past decades. The demographic downturn began in the 1980s, transforming the country into one of the least reproductive societies in the world at the turn of the new millennium (United Nations, 2007). Rural localities have experienced more severe demographic downturn. During the era of rapid industrialization, massive rural-urban migration gradually undermined 
the socioeconomic sustainability of rural communities (Kim, 1988; Lee \& Farber, 1985). Due to the regional disparity in the redistribution of population, local government officials in rural areas perceived the seriousness of the population decline earlier than did national government officials. Those local governments promptly formulated and implemented various policy measures to promote maternity within their jurisdictions prior to the enactment of the national pronatalist policy. After the inception of local maternity policy in 2002, pronatalist policies rapidly spread among local jurisdictions in Korea (Kim, n.d., 2010).

Local maternity policies are highly diverse with regard to the type and amount of benefits as well as eligibility requirements (Ministry of Health, Welfare and Family, 2006, 2008). Local maternity support programs distribute two kinds of benefits: childbirth and child-care support. While the former provides eligible families with immediate lump-sum assistance, the latter provides monthly assistance for child care for a specific time period. Local programs differ in terms of the eligible number of children, ranging from one to five, and the period of support, stretching up to 72 months. The amount of benefits also varies considerably. For example, childbirth support benefits for the third child in a family range from none to 5 million Korean won $(\$ 4,400)$, and child-care support benefits for the entire coverage period for a third child vary from none to 14.4 million won $(\$ 12,600)$.

Why do local governments differ in the generosity of their maternity benefits? At first glance, varying degrees of demographic downturn across localities can be considered as the primary source of local-to-local variation in maternity benefits. That is, one may contend that maternity benefits are likely to be greater in local jurisdictions that have experienced more severe problems of declining and low fertility over the years. Yet, this simplistic view overlooks the confluence of various political and socioeconomic factors in local-level policy making. Numerous factors affect the ways that a policy problem is defined, the issue is placed on a formal agenda, and different policy options are compared during the course of policy formation (Kingdon, 1995; Stone, 2002).

\section{THEORY AND HYPOTHESES}

As outlined in the above section, local governments have set administrative systems in motion to deliver tangible maternity benefits to boost fertility rates in their jurisdictions in Korea, and have established various eligibility criteria and benefit amounts. Why are some local governments more generous than others in providing maternity benefits? To solve this puzzle, this study starts with the idea of female repre- 
sentation within public institutions and the premise that the gender of government officials has a substantial effect on policy outcomes. Yet, as will be discussed in detail, this theoretical explanation may not fully capture the workings of various channels of female influence on policy formulation, especially via two mechanisms of electoral politics: the mobilization of the female constituency and electoral competition. Hence, the study proposes two competing hypotheses linking the electoral power of female citizens to policy outcomes, constituting alternative channels of female influence.

\section{Female Representation}

The theory of representative government can offer a first explanation for the local variation in the generosity of maternity benefits. Proponents of this theory contend that the interests of women can be better represented in policy outcomes primarily by women who hold governmental positions (Keiser et al., 2002; Meier \& NicholsonCrotty, 2006). In other words, the 'descriptive' representation of women in public institutions is considered a precondition for the achievement of active gender representation in policy outcomes (Mosher, 1982, pp. 14-17; cf. Pitkin, 1967). This assertion is grounded on the assumption that government officials are more receptive to the demands of citizens from similar demographic origins (Meier \& Stewart, 1992; Selden, 1997). Because female officials are expected to use their authority to enhance the interests of female citizens, a higher degree of female representation in public institutions is predicted to result in greater policy benefits for women. ${ }^{1}$

Because maternity policies affect the well-being of women as a group, female officials in government institutions are likely to develop shared values and attitudes about the issue based on their sense of "women as mothers" (Ruddick, 1989; also see Shapiro \& Mahajan, 1986). Female voters may expect that female officeholders will better address women's concerns, and female politicians also utilize political strategy emphasizing their better fit to maternity issues (Herrnson et al., 2003). Female legislators are inclined to meet their constituency's expectations by establishing formal positions relevant to women's issues (Dolan \& Ford, 1995) and by actively participating in the

1. This assertion may be regarded as a traditional feminist approach that perceives gender differences and confines attention to a limited range of gendered policy areas. In contrast, a more recent perspective, gender mainstreaming, which surfaced through the 1995 Beijing Platform for Action at the Fourth United Nations Conference on Women, emphasizes various development strategies to achieve gender equality by comprehensively reshaping the "mainstream" in all aspects of policy formulation and implementation across all domains of policy issues (for a review, see Walby, 2005, and True, 2003). 
formulation of policies that benefit women (Swers, 1998, 2005). In accordance with the representative government thesis, a positive relationship can be expected between the number of female officeholders in local policy-making institutions and the generosity of maternity benefits as follows.

Hypothesis 1: The proportion of female officials in local policy-making institutions will have a positive effect on maternity policy benefits.

\section{Alternative Channels of Female Influence: Female Constituency and Electoral Competition}

The representative government theory has contributed to a better understanding of the origins of feminist policy outcomes. Yet, the theory is still incomplete in that it cannot fully explain why and how policies that benefit women could have been formulated in highly masculine institutional settings. Several historical narratives have shown that in many societies, the social and political rights of women have been achieved by broad feminist movements, not by the transformation of policy-making institutions (Anderson, 1996; Tilly \& Gurin, 1992). Similarly, case studies of social welfare policy development have also discovered that the enfranchisement of women and the emergence of female groups have greatly contributed to the successful enactment of various policies that benefit women (Allard, 2004; Howard, 1992; Skocpol, 1995). These together suggest that the representative government theory may have unfairly neglected the importance of the gender makeup of political inputs.

In the area of maternity policy, female citizens are likely to develop a sense of group interests because they have far greater stakes than male voters in public assistance to maternity (Herrnson et al., 2003). Historically, scholars report that various pro-maternity policies such as maternal leave and benefits have been successfully advocated by women's movement groups (Allard, 2004; Koven \& Michel, 1993; Skocpol, 1995). Female constituency groups' support for elected policy makers can be determined by their assessment of these politicians' positions on maternity issues. This means that elected policy makers, both women and men, are likely to be pressured by the presence of female constituents to increase maternity benefits within their jurisdictions. Such electoral dynamics can create an alternative channel through which the interests of female citizens can be incorporated into the content of maternity policy as follows.

Hypothesis 2: The size of the female constituency will have a positive effect on maternity policy benefits. 
The representative government theory also seems to be based on a narrow conception of the motivation of public officials. Its core assumption is that public officials may behave differently when dealing with citizens of the same demographic origin. However, unlike this gender-based behavioral assumption, the larger literature on electoral politics has presumed that elected policy makers take policy positions strategically in pursuing political goals such as reelection (Fiorina, 1989; Hall, 1996; Mayhew, 1974). Such political incentives for elected officials can have discernable policy consequences, because those policy makers can use their power to formulate policies as a means to cultivate support from a broad set of voters. Research has shown that elected policy makers tend to become more generous in making decisions on policy benefits especially when they are confronted with a greater electoral challenge that makes their political standing more vulnerable (Barrilleaux, Holbrook, \& Langer, 2002; Dye, 1984; Jennings, 1979; Kim, 2008).

If a policy issue becomes salient to the female electorate and a highly contested election is anticipated, then incumbent policy makers are likely to weigh the political value of female votes and attempt to increase support from women by addressing that issue. In the case of local maternity policies, elected policy makers facing greater electoral competition, regardless of their gender, may have stronger motivation to manipulate maternity benefits to appeal to female constituents for the attainment of maximum political gains. Therefore, a positive association is expected between the degree of electoral competition and the generosity of maternity benefits, constituting another mechanism of female influence in the policy process, as follows.

Hypothesis 3: Electoral competition will have a positive effect on maternity policy benefits.

\section{Other Socioeconomic Factors}

Although the focus of this study is on mechanisms of female influence in the policy process, other political and social factors may also affect the formation of maternity policies. First, policy makers may try harder to solve a more pressing social problem. Indicators of detrimental effects of a policy problem on communities can arouse public concerns (Anderson, 2010; Kingdon, 1995), thereby prompting public officials to take action to mitigate these effects (Stone, 2002). When maternity policy benefits are seen as an instrumental response by local governments to address public concerns about declining population and fertility, the following can be expected.

Hypothesis 4: Maternity policy benefits will be greater in local jurisdictions that have experienced a more drastic decline in population. 
Next, ideological leanings of local residents can affect policy outcomes because the political orientations of the general public constitute important policy environments (Berry, Ringquist, Fording, \& Hanson, 1998; Erikson, Wright, \& McIver, 1993; Hill, Leighley, \& Hinton-Anderson, 1995). Local officials are likely to react to the local political atmosphere in formulating policies; government officials in liberal localities, as opposed to conservative ones, tend to be more responsive to the demands of disadvantaged social groups. Regarding the generosity of maternity policies, policy makers in liberal localities are more likely to support programs that are tailored to the wellbeing of women. Hence, we can expect the following regarding the effect of local political orientations.

Hypothesis 5: Maternity policy benefits will be greater in local jurisdictions where the general public is liberal in political orientation.

Finally, the fiscal capacity of local government is an important factor that defines the bounds of policy makers' decisions on programs that expand the range of recipients of public assistance (Plotnick \& Winters, 1985; Tweedie, 1994). Local governments cannot add a new program to the existing list of spending items without considering future fiscal constraints. Because the fiscal capacities of local governments are greatly constrained by economic conditions within their jurisdictions, local maternity benefits are expected to be greater when economic and fiscal conditions are better.

Hypothesis 6: Maternity policy benefits will be greater in local jurisdictions that are economically prosperous.

\section{DATA AND MEASUREMENT}

This study analyzes why and how local governments differ in their policy responses to the problem of declining and low fertility in Korea. Two sets of dependent variables are constructed to measure local variation in maternity benefits. Childbirth supports are measured by the amount of the lump-sum payments to families for a first, second, third, fourth, and fifth childbirth. Child-care supports are measured by the total amount of child-care assistance that is promised to a family that has a first, second, third, fourth, and fifth child. The dependent variables are given in 2008 values. The data for these measures were obtained from 230 local governments in Korea via the procedures mandated by the Administrative Information Disclosure Act.

Several independent variables are constructed to measure various factors constituting 
local policy environments surrounding the maternity policy issue. First, to test the representative government hypothesis $\left(\mathrm{H}_{1}\right)$, the degree of female representation within local policy-making institutions is measured by the female seats variable, which is the percentage of seats occupied by women in local legislatures. ${ }^{2}$ According to the gender representation theory, this variable is expected to have a positive effect on maternity benefits. Second, to test female citizens' political influence on maternity benefits $\left(\mathrm{H}_{2}\right)$, female constituency, the percentage of women in the total voting-age (19 and older) population in each local jurisdiction, is noted. ${ }^{3}$ Third, to examine the consequence of electoral dynamics $\left(\mathrm{H}_{3}\right)$, electoral competition is measured by the difference between the percentages of votes received by the winner and the runner-up in the most recent mayoral election. This measure is reversed (100\% minus the winner's electoral margin), so that a greater value represents a higher level of electoral competition; this variable is expected to have a positive impact on the dependent variables.

Other variables are also created to examine the effects of citizen ideology, the severity of the policy problem, and the economic condition of the locality. To examine the effect of local citizens' ideological leanings, citizen liberalism is measured as the percentage of votes that went to the Democratic Labor Party, the most liberal party in Korea, in the latest local party-list election. The severity of the demographic downturn at the local level is measured by population (the logged number of local residents), change in population (over five years), total fertility rate (number of live births per fertile woman), birthrate (live births per 1,000 local residents), and change in birthrate (over five years). These variables should have negative effects on maternity benefits because policy makers will be less concerned when there is a growing population, higher total fertility rate, and increasing birthrate. To control for the aging of local populations, elderly dependence is measured by the ratio of population aged 65 and over to population aged 15-64 in each local jurisdiction, with an expectation of a positive impact on maternity benefits.

Economic conditions in a locality may determine the fiscal resources it can devote to maternity support programs. This study uses the variables gross regional product, the log-transformed gross regional production in each provincial or metropolitan jurisdiction, fiscal capacity of local government, measured by per capita local tax, and companies, the logged number of companies in each locality, which represents the

2. Although the policy-making power of executive heads is also substantial, a measure for a gender profile of the executive heads was excluded due to the lack of variation in the number of female mayors.

3. This variable is chosen because it better represents the electoral power of female citizens than some alternative measures, including the proportion of fertile women aged 15-49. 
level of economic development. As a measure of economic hardship, the welfare households variable, the number of households receiving welfare benefits per 1,000 local residents, is also included in the equation.

Finally, to control for the gap in demographic conditions between metropolitan and nonmetropolitan areas, two dummy variables_ rural, which indicates townships in rural areas (gun), and metropolitan, which indicates autonomous districts in metropolitan areas $(\mathrm{gu})$ - are created. The base for this set of dummy variables is municipalities in nonmetropolitan areas (si). Since the Korean population has increasingly been concentrated in the metropolitan cities, maternity benefits are expected to be greater in nonmetropolitan areas. Table 1 summarizes the variables used in this study. Descriptive statistics for these variables are given in the appendix.

Table 1. Variables and Measurements

\begin{tabular}{|c|c|c|}
\hline Variables & Description of measurement & Hypothesis \\
\hline \multicolumn{3}{|l|}{ Dependent variables } \\
\hline Childbirth support $(1,2,3,4,5)$ & $\begin{array}{l}\text { Immediate benefits for childbirth for the 1st, 2nd, 3rd, 4th, } \\
\text { and 5th child }\end{array}$ & \\
\hline Child-care support $(1,2,3,4,5)$ & $\begin{array}{l}\text { Total child-care benefits for the 1st, 2nd, 3rd, 4th, and 5th } \\
\text { child }\end{array}$ & \\
\hline \multicolumn{3}{|l|}{ Independent variables } \\
\hline Female seats & $\begin{array}{l}\text { Percentage of seats occupied by women in each local } \\
\text { legislature }\end{array}$ & $\mathrm{H} 1(+)$ \\
\hline Female constituency & $\begin{array}{l}\text { Percentage of female voters in total voting-age population } \\
\text { in each local jurisdiction }\end{array}$ & $\mathrm{H} 2(+)$ \\
\hline Electoral competition & $\begin{array}{l}\text { Reverse of winner's electoral margin ( } 100 \% \text { minus margin) } \\
\text { in the latest mayoral election }\end{array}$ & $\mathrm{H} 3(+)$ \\
\hline Citizen liberalism & $\begin{array}{l}\text { Percentage of votes for the Democratic Labor Party } \\
\text { candidate in the last local election }\end{array}$ & $\mathrm{H} 4(+)$ \\
\hline Population (In) & Population in each local jurisdiction (logged) & H5 (-) \\
\hline Change in population & Change in population over 5 years in each local jurisdiction & H5 (-) \\
\hline Total fertility rate & $\begin{array}{l}\text { Number of live births per fertile woman in each local } \\
\text { jurisdiction }\end{array}$ & H5 (-) \\
\hline Birthrate & Number of live births per 1,000 local residents & H5 (-) \\
\hline Change in birthrate & Change in birthrate over 5 years in each local jurisdiction & H5 (-) \\
\hline Elderly dependence & $\begin{array}{l}\text { Ratio of the } 65 \text {-and-older population to the 15-64-year-old } \\
\text { population in each local jurisdiction }\end{array}$ & $\mathrm{H} 5(+)$ \\
\hline Gross regional product (ln) & $\begin{array}{l}\text { Gross regional product (logged) in each provincial or } \\
\text { metropolitan jurisdiction }\end{array}$ & $\mathrm{H} 6(+)$ \\
\hline
\end{tabular}




\begin{tabular}{l|l|c}
\hline \multicolumn{1}{c|}{ Variables } & \multicolumn{1}{c}{ Description of measurement } & Hypothesis \\
\hline Fiscal capacity & Per capita local tax in each local jurisdiction & $\mathrm{H} 6(+)$ \\
\hline Companies (In) & Number of companies (logged) in each local jurisdiction & $\mathrm{H} 6(+)$ \\
\hline Welfare households & $\begin{array}{l}\text { Number of households receiving welfare benefits per } \\
1,000 \text { local residents }\end{array}$ & $\mathrm{H} 6(+)$ \\
\hline Controls & \multicolumn{2}{|l}{} \\
\hline Rural & Townships in rural areas & \\
\hline Metropolitan & Autonomous districts in metropolitan areas & \\
\hline
\end{tabular}

\section{FINDINGS}

The theory of representative government contends that the interests of women are better served during the policy process by female officials within government institutions. In addition to this widely known channel of representation for women, the present study attempts to test for the effectiveness of other mechanisms of active representation for women in the policy process. It has been proposed that the presence of a larger female constituency and a higher level of electoral competition can render policy makers, regardless of their gender, more receptive to the influence of women in the citizenry, thereby promoting the attainment of women's interests in the policy formation process. In this section, these theoretical possibilities are empirically examined by conducting cross-sectional analyses on local variation in Korea in the two kinds of maternity benefits, childbirth and child-care support.

\section{Local Childbirth Support Benefits}

Table 2 presents the results for local childbirth support benefits. To explore the policy effect of gender diversity within government institutions, the female seats variable can be examined. The female representation theory predicts that the gender of public officials does matter in determining policies that benefit female citizens and the presence of a substantial number of female officials leads to decisions to provide greater benefits for maternity. Contrary to this theoretical expectation, the analysis result shows a lack of significant influence by the proportion of female legislators on the amount of childbirth support benefits. Coefficients on female seats are not statistically significant at all across different equations for the first to fifth child of a family. This means that the degree of female representation within local policy-making institutions (that is, local legislatures) does not make any discernible difference in determining the amount 
132 Female Constituency, Electoral Competition, and Local Maternity Policy in Korea

Table 2. OLSAnalysis of Local Childbirth Support Benefits in Korea

\begin{tabular}{|c|c|c|c|c|c|}
\hline \multirow{2}{*}{ Variables } & \multicolumn{5}{|c|}{ Childbirth support } \\
\hline & 1st child & 2nd child & 3rd child & 4th child & 5th child \\
\hline Female seats & $\begin{array}{l}1.935 \\
(1.431)\end{array}$ & $\begin{array}{l}1.868 \\
(2.724)\end{array}$ & $\begin{array}{l}-6.165 \\
(6.336)\end{array}$ & $\begin{array}{l}-0.326 \\
(8.171)\end{array}$ & $\begin{array}{l}2.223 \\
(9.265)\end{array}$ \\
\hline Female constituency & $\begin{array}{c}-0.439 \\
(18.928) \\
\end{array}$ & $\begin{array}{l}51.852 * \\
(30.084) \\
\end{array}$ & $\begin{array}{c}220.486 * * \\
(72.365) \\
\end{array}$ & $\begin{array}{c}283.166 * * * \\
(79.188)\end{array}$ & $\begin{array}{c}322.424 * * \\
(114.216) \\
\end{array}$ \\
\hline Electoral competition & $\begin{array}{c}0.851 \\
(0.554)\end{array}$ & $\begin{array}{r}2.652^{* *} \\
(0.554)\end{array}$ & $\begin{array}{l}3.047 * \\
(3.047)\end{array}$ & $\begin{array}{r}7.696 * * \\
(3.204)\end{array}$ & $\begin{array}{c}10.480 * * \\
(3.935)\end{array}$ \\
\hline Citizen liberalism & $\begin{array}{c}-7.176 * * \\
(2.281)\end{array}$ & $\begin{array}{l}-2.091 \\
(4.925)\end{array}$ & $\begin{array}{r}43.107 * * \\
(16.506)\end{array}$ & $\begin{array}{l}36.458^{*} \\
(16.989)\end{array}$ & $\begin{array}{l}\text { 38.429* } \\
(17.544)\end{array}$ \\
\hline Population (In) & $\begin{array}{l}-16.233 \\
(40.190)\end{array}$ & $\begin{array}{c}-170.267^{*} \\
(74.883)\end{array}$ & $\begin{array}{c}-690.121^{* *} \\
(246.282)\end{array}$ & $\begin{array}{c}-766.680 * * * \\
(236.369)\end{array}$ & $\begin{array}{c}-834.931 * * \\
(288.365)\end{array}$ \\
\hline Change in population & $\begin{array}{l}-2.585^{*} \\
(1.323)\end{array}$ & $\begin{array}{l}-1.153 \\
(2.850)\end{array}$ & $\begin{array}{l}6.576 \\
(6.014)\end{array}$ & $\begin{array}{c}7.289 \\
(6.274)\end{array}$ & $\begin{array}{l}6.614 \\
(6.994)\end{array}$ \\
\hline Total fertility rate & $\begin{array}{c}112.005 \\
(183.126)\end{array}$ & $\begin{array}{c}56.445 \\
(294.571)\end{array}$ & $\begin{array}{l}-374.333 \\
(651.214)\end{array}$ & $\begin{array}{l}-218.186 \\
(714.186)\end{array}$ & $\begin{array}{l}-205.568 \\
(881.225)\end{array}$ \\
\hline Birthrate & $\begin{array}{c}-2.727 \\
(15.099)\end{array}$ & $\begin{array}{c}0.292 \\
(27.188)\end{array}$ & $\begin{array}{c}-3.870 \\
(60.277)\end{array}$ & $\begin{array}{l}-21.639 \\
(68.803)\end{array}$ & $\begin{array}{l}-70.564 \\
(82.862)\end{array}$ \\
\hline Change in birthrate & $\begin{array}{l}\text { 21.357* } \\
(11.403)\end{array}$ & $\begin{array}{l}13.578 \\
(22.510)\end{array}$ & $\begin{array}{c}71.398 \\
(68.739)\end{array}$ & $\begin{array}{c}120.984 * \\
(72.179)\end{array}$ & $\begin{array}{c}155.166^{*} \\
(77.566)\end{array}$ \\
\hline Elderly dependence & $\begin{array}{l}8.000 * \\
(4.534)\end{array}$ & $\begin{array}{l}13.247^{*} \\
(6.739)\end{array}$ & $\begin{array}{l}23.290 \\
(20.012)\end{array}$ & $\begin{array}{c}8.942 \\
(21.075)\end{array}$ & $\begin{array}{c}-4.358 \\
(24.198)\end{array}$ \\
\hline Gross regional product (In) & $\begin{array}{l}-27.115^{*} \\
(14.340) \\
\end{array}$ & $\begin{array}{l}24.707 \\
(27.870)\end{array}$ & $\begin{array}{c}135.602^{*} \\
(67.349)\end{array}$ & $\begin{array}{c}148.619 * \\
(76.254)\end{array}$ & $\begin{array}{c}165.263^{*} \\
(90.446)\end{array}$ \\
\hline Fiscal capacity & $\begin{array}{l}-0.018 \\
(0.083)\end{array}$ & $\begin{array}{c}0.049 \\
(0.212)\end{array}$ & $\begin{array}{c}0.018 \\
(0.524)\end{array}$ & $\begin{array}{l}1.288 * * \\
(0.542)\end{array}$ & $\begin{array}{r}2.447 * * \\
(0.989)\end{array}$ \\
\hline Companies (In) & $\begin{array}{c}-4.511 \\
(35.596)\end{array}$ & $\begin{array}{l}100.609 \\
(76.464)\end{array}$ & $\begin{array}{r}635.204 * * \\
(233.269)\end{array}$ & $\begin{array}{c}790.051 * * * \\
(225.904)\end{array}$ & $\begin{array}{c}1,010.189 * * * \\
(288.444)\end{array}$ \\
\hline Welfare households per 1,000 & $\begin{array}{c}-2.358^{*} \\
(1.246)\end{array}$ & $\begin{array}{l}-3.738^{*} \\
(1.947)\end{array}$ & $\begin{array}{l}-6.480 \\
(4.440)\end{array}$ & $\begin{array}{l}-2.733 \\
(4.929)\end{array}$ & $\begin{array}{l}1.947 \\
(5.711)\end{array}$ \\
\hline Rural & $\begin{array}{c}64.457 \\
(51.499)\end{array}$ & $\begin{array}{c}161.257^{*} \\
(75.038)\end{array}$ & $\begin{array}{c}171.109 \\
(199.053)\end{array}$ & $\begin{array}{l}-116.634 \\
(213.006) \\
\end{array}$ & $\begin{array}{l}-225.617 \\
(229.632) \\
\end{array}$ \\
\hline Metropolitan & $\begin{array}{c}30.612 \\
(57.284) \\
\end{array}$ & $\begin{array}{c}64.328 \\
(91.655) \\
\end{array}$ & $\begin{array}{l}-306.785 \\
(270.135) \\
\end{array}$ & $\begin{array}{l}-505.592 \\
(291.729) \\
\end{array}$ & $\begin{array}{c}-580.669 * \\
(321.219) \\
\end{array}$ \\
\hline Constant & $\begin{array}{c}604.457 \\
(1,004.789)\end{array}$ & $\begin{array}{c}-2,187.832 \\
(1,708.201)\end{array}$ & $\begin{array}{c}-10,988.780 * * \\
(3,939.959)\end{array}$ & $\begin{array}{c}-14,865.320 * * * \\
(4,345.436)\end{array}$ & $\begin{array}{c}-18,640.880 * * \\
(6,030.997)\end{array}$ \\
\hline Number of observations & 230 & 230 & 230 & 230 & 230 \\
\hline R-square & 0.354 & 0.295 & 0.288 & 0.277 & 0.261 \\
\hline
\end{tabular}

Note: Robust standard errors are in parentheses.

$* p<0.05, * * p<0.01, * * * p<0.001$ (one-tailed tests)

The Korean Journal of Policy Studies 
of childbirth support benefits across local jurisdictions.

Even when female representation within public institutions does not effectively shape policy decisions on maternity benefits, there are alternative channels for female influence which affect the way that elected officials, regardless of their sex, formulate policies for women. Both the strength of the female constituency and the level of electoral competition turn out to be significant factors. More specifically, female constituency is significant in exerting a positive influence on the amount of childbirth benefits for a family having a second to fifth child. This finding lends support to the competing hypothesis that the electoral power of women in the citizenry, as opposed to the sheer number of female officials, induces the formation of a gendered policy by constraining both male and female officials' decisions. The effect is estimated to be highly significant: a one-unit increase in the percentage of women in the local population is estimated to have a positive effect of as much as 51,852 won, 220,486 won, 283,166 won, and 322,424 won, respectively, on the childbirth benefit for a second, third, fourth, and fifth child.

The effects of electoral competition also consistently support the proposition that the electoral incentives of policy makers influence policy decisions that benefit female constituents. This variable is estimated to have positive effects on childbirth benefits: a one-standard-deviation increase in electoral competition (17.76) tends to increase maternity benefits by as much as 47,099 won $(=2,652 * 17.76)$ for a second child, 54,110 won $(=3,047 * 17.76)$ for a third child, 138,460 won $(=7,796 * 17.76)$ for a fourth child, and 186,160 won $(=10,480 * 17.76)$ for a fifth child. These results suggest that local policy makers facing greater political challenge are likely to support maternity policies in order to cultivate political support from female voters.

Other socioeconomic factors are expected to have an effect on local childbirth support benefits. Citizen liberalism turns out to be significant in increasing the maternity benefits for a third, fourth, or fifth child, thereby supporting the hypothesis: a 1 percent increase in votes for the Democratic Labor Party is associated with an increase in childbirth benefits by as much as 43,107 won, 36,458 won, and 38,429 won for a third, fourth, and fifth child, respectively. Regarding the severity of the policy problem, population $(\ln )$ has a negative effect on the level of childbirth benefits, as predicted by the hypothesis: a 1 percent increase in local population is estimated to reduce childbirth benefits by 170,267 won, 690,121 won, 766,680 won, and 834,931 won for a second to fifth child, respectively. Economic factors also matter for maternity benefits, as the hypothesis predicted. The variables gross regional product (ln) and companies (ln) are estimated to have a positive effect on the amount of childbirth support benefits, especially for the third to fifth child of a family. A 1 percent increase in gross regional product tends to increase benefits by as much as 135,602 to 165,263 won, and a 1 
percent increase in the number of companies tends to increase benefits by 635,204 to $1,010,189$ won.

In sum, the primary findings shown in table 2 indicate that the degree of female representation within local policy-making institutions cannot account for local variation in the generosity of childbirth support benefits. Despite the fact that childbirth support policies may enhance the interests of female citizens, there is no significant association between the gender of policy makers and the amount of maternity benefits. Yet, when the role of female representation is limited, this analysis demonstrates that alternative channels for the active representation of women, which affect both male and female policy makers' behavior, are crucial in shaping local maternity policy. The findings collectively confirm that the strength of the female constituency and the electoral incentives of the incumbent policy makers significantly contribute to the provision of greater childbirth benefits.

\section{Local Child-Care Support Benefits}

Table 3 summarizes the results of the analysis of local variation in child-care support benefits. The findings show that the strength of the female constituency is the factor that has, as expected, the most consistently positive effect on child-care benefits across different equations. However, other channels of female influence, such as the proportion of female legislators and electoral competition, are not consistent with expectations in terms of their effects on the generosity of childbirth benefits.

First, the hypothesis of representative government is not consistently supported. The effects of the female seats variable are mixed at best: this variable has a positive effect on child-care benefits for a second child, but it has an unexpectedly negative effect on benefits for a fourth and fifth child. Combined with the lack of any significant link between the degree of female representation within local policy-making institutions and the amount of childbirth support benefits, this result suggests that the generosity of maternity benefits is not determined by the gender profile of local policy-making institutions in Korea.

It has also been hypothesized that when female representation within government institutions fails to formulate greater policy benefits for women, other channels of female influence that can shape the behavioral patterns of public officials, regardless of their gender, can enhance female citizens' interests in policy. An alternative channel is the electoral competition that policy makers are likely to face, which may increase the political value of female votes. The preceding analysis of childbirth support benefits has confirmed this theoretical expectation by showing a positive association between electoral competition and the amount of benefits. Yet, when this variable is 
Table 3. OLSAnalysis of Local Child-Care Support Benefits in Korea

\begin{tabular}{|c|c|c|c|c|c|}
\hline \multirow{2}{*}{ Variables } & \multicolumn{5}{|c|}{ Child-Care Support } \\
\hline & 1st child & 2nd child & 3rd child & 4th child & 5th child \\
\hline Female seats & $\begin{array}{c}3.953 \\
(2.596)\end{array}$ & $\begin{array}{l}8.049 * \\
(4.441)\end{array}$ & $\begin{array}{l}-27.886 \\
(20.949)\end{array}$ & $\begin{array}{l}-43.338^{*} \\
(22.213)\end{array}$ & $\begin{array}{l}-43.948^{*} \\
(22.273) \\
\end{array}$ \\
\hline Female constituency & $\begin{array}{l}47.998 \\
(31.192) \\
\end{array}$ & $\begin{array}{c}132.294^{*} \\
(66.608) \\
\end{array}$ & $\begin{array}{r}692.844 * * \\
(284.465) \\
\end{array}$ & $\begin{array}{l}544.588^{*} \\
(288.152) \\
\end{array}$ & $\begin{array}{l}534.655^{*} \\
(289.003) \\
\end{array}$ \\
\hline Electoral competition & $\begin{array}{l}-1.099 \\
(0.839)\end{array}$ & $\begin{array}{l}-2.671 \\
(1.975)\end{array}$ & $\begin{array}{c}-23.346^{* *} \\
(9.504)\end{array}$ & $\begin{array}{c}-18.790^{*} \\
(9.504)\end{array}$ & $\begin{array}{c}-18.380^{*} \\
(9.912)\end{array}$ \\
\hline Citizen liberalism & $\begin{array}{l}-7.495^{*} \\
(3.255)\end{array}$ & $\begin{array}{c}-20.578^{*} \\
(9.306)\end{array}$ & $\begin{array}{l}84.744^{*} \\
(45.199)\end{array}$ & $\begin{array}{c}105.817^{*} \\
(46.108)\end{array}$ & $\begin{array}{c}105.028 * \\
(46.116)\end{array}$ \\
\hline Population (In) & $\begin{array}{c}-6.288 \\
(59.239)\end{array}$ & $\begin{array}{l}-87.247 \\
(99.714)\end{array}$ & $\begin{array}{c}-1,452.679 * \\
(646.211)\end{array}$ & $\begin{array}{c}-1,521.791^{*} \\
(669.671)\end{array}$ & $\begin{array}{c}-1,497.336 * \\
(671.872)\end{array}$ \\
\hline Change in population & $\begin{array}{l}-3.304 \\
(2.339)\end{array}$ & $\begin{array}{l}-4.526 \\
(3.843)\end{array}$ & $\begin{array}{c}68.172 * * \\
(27.119)\end{array}$ & $\begin{array}{c}72.133 * * \\
(28.341)\end{array}$ & $\begin{array}{c}71.849 * * \\
(28.345)\end{array}$ \\
\hline Total fertility rate & $\begin{array}{c}-1,031.278^{* *} \\
(389.556)\end{array}$ & $\begin{array}{c}1,780.696 * * \\
(636.812)\end{array}$ & $\begin{array}{c}1,661.711 \\
(2,023.547)\end{array}$ & $\begin{array}{c}16.448 \\
(2,096.662)\end{array}$ & $\begin{array}{c}-78.498 \\
(2,105.907)\end{array}$ \\
\hline Birthrate & $\begin{array}{c}-70.741 * \\
(31.154)\end{array}$ & $\begin{array}{c}-105.327 * \\
(47.948)\end{array}$ & $\begin{array}{l}-162.802 \\
(185.895)\end{array}$ & $\begin{array}{c}-58.202 \\
(191.996)\end{array}$ & $\begin{array}{c}-51.607 \\
(192.492)\end{array}$ \\
\hline Change in birthrate & $\begin{array}{c}61.593 * * * \\
(19.264)\end{array}$ & $\begin{array}{c}14.046 \\
(63.468)\end{array}$ & $\begin{array}{l}-135.372 \\
(165.823)\end{array}$ & $\begin{array}{l}-250.602 \\
(173.503)\end{array}$ & $\begin{array}{l}-246.158 \\
(173.782)\end{array}$ \\
\hline Elderly dependence & $\begin{array}{l}-6.550 \\
(4.436)\end{array}$ & $\begin{array}{l}-20.024^{*} \\
(11.737)\end{array}$ & $\begin{array}{l}73.075 \\
(57.672)\end{array}$ & $\begin{array}{l}83.248 \\
(57.744)\end{array}$ & $\begin{array}{l}85.074 \\
(57.918)\end{array}$ \\
\hline Gross regional product (In) & $\begin{array}{l}42.467 \\
(35.001) \\
\end{array}$ & $\begin{array}{l}104.642 \\
(69.513)\end{array}$ & $\begin{array}{r}555.847 * * \\
(222.615) \\
\end{array}$ & $\begin{array}{r}592.203^{* *} \\
(225.774)\end{array}$ & $\begin{array}{l}591.418^{*} \\
(225.729)\end{array}$ \\
\hline Fiscal capacity & $\begin{array}{c}0.060 \\
(0.183)\end{array}$ & $\begin{array}{l}0.066 \\
(0.267)\end{array}$ & $\begin{array}{l}-3.316^{*} \\
(1.673)\end{array}$ & $\begin{array}{l}-3.638^{*} \\
(1.587)\end{array}$ & $\begin{array}{l}-3.573^{*} \\
(1.583)\end{array}$ \\
\hline Companies (In) & $\begin{array}{l}19.073 \\
(66.905)\end{array}$ & $\begin{array}{l}110.326 \\
(99.809)\end{array}$ & $\begin{array}{c}1,243.767 * \\
(587.547)\end{array}$ & $\begin{array}{c}1,258.051^{*} \\
(606.760)\end{array}$ & $\begin{array}{c}1,234.517^{*} \\
(608.426)\end{array}$ \\
\hline Welfare households per 1,000 & $\begin{array}{c}0.480 \\
(2.002)\end{array}$ & $\begin{array}{l}6.361 \\
(6.021)\end{array}$ & $\begin{array}{c}-6.825 \\
(14.499)\end{array}$ & $\begin{array}{c}-5.696 \\
(14.505)\end{array}$ & $\begin{array}{c}-5.062 \\
(14.581)\end{array}$ \\
\hline Rural & $\begin{array}{l}80.956 \\
(56.466) \\
\end{array}$ & $\begin{array}{c}-3.307 \\
(163.968)\end{array}$ & $\begin{array}{l}-262.492 \\
(494.235) \\
\end{array}$ & $\begin{array}{l}-315.991 \\
(489.771) \\
\end{array}$ & $\begin{array}{l}-269.539 \\
(501.767) \\
\end{array}$ \\
\hline Metropolitan & $\begin{array}{c}176.998^{*} \\
(92.303) \\
\end{array}$ & $\begin{array}{c}139.071 \\
(165.622) \\
\end{array}$ & $\begin{array}{l}-473.891 \\
(661.844) \\
\end{array}$ & $\begin{array}{l}-616.134 \\
(663.939) \\
\end{array}$ & $\begin{array}{c}586.837 \\
(667.664) \\
\end{array}$ \\
\hline Constant & $\begin{array}{c}-3,736.296 * * \\
(1,590.588)\end{array}$ & $\begin{array}{c}-9,332.417 * \\
(4,112.104)\end{array}$ & \begin{tabular}{|c|}
$-38,017.800^{* *}$ \\
$(14,670.540)$ \\
\end{tabular} & $\begin{array}{l}-29,960.150^{*} \\
(14,934.770)\end{array}$ & $\begin{array}{r}-29,560.050^{*} \\
(14,955.250)\end{array}$ \\
\hline Number of observations & 230 & 230 & 230 & 230 & 230 \\
\hline R-square & 0.210 & 0.172 & 0.304 & 0.270 & 0.268 \\
\hline
\end{tabular}

Note: Robust standard errors are in parentheses.

$* p<0.05,{ }^{* *} p<0.01$, ${ }^{* * *} p<0.001$ (one-tailed tests) 
examined in connection with child-care support benefits, the electoral competition hypothesis is not supported at all. Unlike the hypothesized relationship, negative coefficients on electoral competition indicate that a higher level of electoral competition tends to decrease child-care benefits, especially for the third to fifth child.

In contrast, the results consistently support the hypothesis that the presence of a larger female constituency can lead local policy makers to provide greater maternity benefits. Coefficients on the female constituency variable mean that a 1 percent increase in the size of the female constituency in a local jurisdiction tends to increase the amount of child-care benefits by as much as 132,294 won, 692,844 won, 544,588 won, and 534,655 won for the second, third, fourth, and fifth child of a family, respectively. Together with the preceding evidence for the effect of this mechanism on childbirth benefits, it is clear that this variable performs consistently across benefit types for maternity support. Hence, one can conclude that the electoral mobilization of female citizens can overcome the gender divide in policy formulation by placing pressure on elected officials, regardless of their sex, to address the concerns of women.

Turning to other factors, it is found that the ideological leanings of local residents significantly affect the amount of local maternity benefits. Citizen liberalism has a positive effect on child-care benefits: a 1 percent increase in votes for the Democratic Labor Party is associated with an increase of 84,744 won, 105,817 won, and 105,028 won in the amount of child-care benefits for the third to fifth child of a family. It is also shown that the amount of child-care support benefits is smaller in localities where the problem of demographic downturn is less severe, and it is greater in localities where economic conditions are better. Negative coefficients on population $(\ln )$ indicate that a 1 percent increase in the size of the local population tends to decrease the amount of child-care benefits by as much as 1,452,679 to 1,521,791 won for the third to fifth child of a family. Furthermore, a 1 percent increase in gross regional product is associated with an increase in child-care benefits of as much as 555,841 to 592,203 won for the third to fifth child. And a 1 percent increase in the number of companies is estimated to increase child-care benefits by as much as $1,234,767$ to $1,258,051$ won for a third to fifth child.

Overall, the empirical patterns reported in tables 2 and 3 demonstrate that the strength of the female constituency has the most consistently positive effect on both childbirth and child-care benefits. Electoral competition has the expected effect on childbirth benefits but not on child-care benefits. Gender diversity within local legislatures turns out to be the least influential factor and does not have any effect on either benefit. These results together suggest that the mobilization of female interests and political competition among elected policy makers can constitute alternative channels through which female citizens can advance their issues to policy decisions even if 
female officeholders in government institutions are not sufficiently empowered to protect women's interests during the formation of public policies.

\section{CONCLUSION}

This study has examined how the interests of women are translated into policy outputs in the context of local maternity support policies in Korea. It clearly shows that the proportion of women in local policy-making institutions plays a very limited role in forming maternity policies in Korea. This finding may be surprising to those who have regarded gender equality in government as the key facilitator of the translation of women's interests into greater policy benefits for female citizens. However, this study is not the first to show that the enactment of policies that benefit women has not been dependent upon an advance of female officials in number and power within public organizations in Korea. Prior research has shown that women's rights have successfully been incorporated into national legislation due primarily to the strategic mobilization of female voters and groups, while female representation in elected institutions and bureaucratic organizations has remained very low in Korea (e.g., Lee, 1996; Lee \& Chin, 2007).

How can policies for women be enacted if women inside public institutions are not sufficiently empowered to represent female interests? The results of this study provide strong empirical support for the theoretical expectation that there are alternative channels of female representation through which elite policy makers and female citizens interact. This study highlights the ways that elected policy makers, regardless of gender, are pressured to become more attentive to the concerns of women. Even when the political base of women inside policy-making institutions remains weak and, hence, important policy decisions are made in mostly masculine institutional arrangements, the mobilization of female constituents on the one hand and electoral competition on the other hand can create political conditions that foster a significant association between elected policy makers' decisions and the intensity of women's interests in a polity.

These two mechanisms of female influence are clearly distinct from that of gender equality in the composition of government institutions. First, the alternative channels of female representation operate on the input side of the political process. Female constituency groups can mobilize political resources to enlarge the space for women's issues in the government agenda and help prioritize policies that benefit women. This study confirms that the dynamics of interest mobilization for women can substantially affect the results of the local policy-making process. Second, these channels of female 
representation can constrain the ways that both female and male officeholders deal with gendered policy issues. If the attainment of gender equality in government is limited, then it is important for advocates of women's issues to cultivate support from male officeholders who are predominant in number and influence within policymaking institutions. This study suggests that electoral competition creates a window of opportunity to advance women's issues in the policy process.

Hence, the findings of this study suggest that maternity policy formulation can be understood as a process that is constrained by the confluence of universal factors that may be at work across a broad range of policy domains. As discussed above, the local maternity policy domain under study has attributes that may bring about a gender divide among public officials within policy-making institutions. Nonetheless, this policy domain seems to be characterized primarily by such universal factors as the influence of the policy target population and the political motivations of elected policy makers, which can apply to other policy areas besides the maternity issue in decentralized policy systems (Hill et al., 1995; Im, 2002; Kim, 2008, 2011).

Finally, a larger implication stemming from this study is that the process of representative democracy can be considered as conducive to the formation of policies that promote women's interests in the policy process. Even in a polity, such as Korea, where public organizations are still dominated by male officials and limited in rendering discernible policy effects for women, the normal politics of interest mobilization and electoral competition can function as vital agents for making masculine policy-making institutions more receptive to the demands of women.

\section{REFERENCES}

Allard, S. W. 2004. Competitive pressures and the emergence of mothers' aid programs in the United States. Policy Studies Journal, 32(4): 521-44.

Anderson, J. 2010. Public policymaking: An introduction (7th ed.). Boston: Wadsworth.

Anderson, K. 1996. After suffrage: Women in partisan and electoral politics before the New Deal. Chicago: University of Chicago Press.

Barrilleaux, C., Holbrook, T., \& Langer, L. 2002. Electoral competition, legislative balance, and American state welfare policy. American Journal of Political Science, 46(2): 413-27.

Berry, W. D., Ringquist, E. J., Fording, R., \& Hanson, R. 1998. Measuring citizen and government ideology in the American states, 1960-93. American Journal of Political Science, 42(1): 327-48.

Dolan, J. 1997. Support for women's interests in the 103d Congress: The district 
impact of Congressional women. Women and Politics, 18(1): 81-94.

. 2000. The senior executive service: Gender, attitudes and representative bureaucracy. Journal of Public Administration Research and Theory, 10(3): 513-29.

Dolan, J., \& Ford, L. E. 1995. Women in the state legislatures: Feminist identity and legislative behaviors. American Politics Research, 23(1): 96-108.

Dye, T. R. 1984. Party and policy in the states. Journal of Politics, 46(4): 1097-116.

Erikson, R. S., Wright, G. C., \& McIver, J. P. 1993. Statehouse democracy. New York: Cambridge University Press.

Fiorina, M. P. 1989. Congress: Keystone of the Washington establishment (2nd ed.). New Haven: Yale University Press.

Hall, R. L. 1996. Participation in Congress. New Haven: Yale University Press.

Herrnson, P. S., Lay, J. C., \& Stokes, A. K. 2003. Women running "as women": Candidate gender, campaign issues, and voter-targeting strategies. Journal of Politics, 65(1): 244-55.

Hill, K. Q., Leighley, J. E., \& Hinton-Anderson, A. 1995. Lower class mobilization and policy linkage in the U.S. states. American Journal of Political Science, 39(1): 75-86.

Howard, C. 1992. Sowing the seeds of "welfare": The transformation of mothers' pensions, 1900-1940. Journal of Policy History, 4(2): 188-227.

Im, T. B. 2002. Evaluating 10 years' experiences of decentralization: The emphasis of intergovernmental relations and decision-making structure. Korean Journal of Policy Studies, 16(2): 11-22.

Jennings, E. T. 1979. Competition, constituencies, and welfare policies in American states. American Political Science Review, 73(2): 414-29.

Keiser, L. R., Wilkins, V. M., Meier, K. J., \& Holland, C. 2002. Lipstick and logarithms: Gender, institutional context, and representative bureaucracy. American Political Science Review, 96(3): 553-64.

Kelly, R. M., \& Newman, M. 2001. The gendered bureaucracy: Agency mission, equality of opportunity, and representative bureaucracies. Women and Politics, 22(3): 1-34.

Kim, D.-R. 2008. The dynamics of Korean policy process: Intergovernmental competition, political interests, and local welfare spending. International Review of Public Administration, 13(1): 47-57.

. 2010. The dynamics of local fertility policy diffusion in Korea. Paper presented at the annual conference of the Midwest Political Science Association, Chicago.

2011. Do local policy networks deter the race to the bottom in environmental 
regulation? The case of South Korea. Environment and Planning C: Government and Policy, 29(6): 1037-53.

. n.d. Local government policy diffusion in a decentralised system: Childbirth support policy in South Korea. Local Government Studies forthcoming.

Kim, W. B. 1988. Population redistribution policy in Korea: A review. Population Research and Policy Review, 7(1): 49-77.

Kingdon, J. W. 1995. Agendas, alternatives, and public policies (2nd ed.). New York: Longman.

Lee, A.-R. 1996. Consistency or change in women's politicization in South Korea. Policy Studies Journal, 24(2): 183-200.

Lee, A.-R., \& Chin, M. 2007. The women's movement in South Korea. Social Science Quarterly, 88(5): 1205-26.

Lee, B. S., \& Farber, S. C. 1985. The influence of rapid rural-urban migration on Korean national fertility levels. Journal of Development Economics, 17(1): 47-71.

Mansbridge, J. 1999. Should blacks represent blacks and women represent women? A contingent "yes." Journal of Politics, 61(3): 628-57.

Mayhew, D. R. 1974. Congress: The electoral connection. New Haven: Yale University Press.

Meier, K. J., \& Nicholson-Crotty, J. 2006. Gender, representative bureaucracy, and law enforcement: The case of sexual assault. Public Administration Review, 66(6): 850-60.

Meier, K. J., \& Stewart, J. 1992. Active representation in educational bureaucracies: Policy impacts. American Review of Public Administration, 22(3): 157-71.

Ministry of Health, Welfare and Family. 2006. 2006 Local government fertility policy cases [in Korean]. Seoul: Author.

2008. 2008 Local government population policy cases [in Korean]. Seoul: Author.

Mosher, F. 1982. Democracy and the public service (2nd ed.). New York: Oxford University Press.

Mouffe, C. 1995. Feminism, citizenship and radical democratic politics. In L. Nicholson \& S. Seidman (eds.), Social postmodernism: Beyond identity politics (pp. 369-84). New York: Cambridge University Press.

Pateman, C. 1989. The disorder of women: Democracy, feminism and political theory. Stanford: Stanford University Press.

Pitkin, H. F. 1967. The concept of representation. Berkeley: University of California Press.

Plotnick, R. D., \& Winters, R. 1985. A politico-economic theory of income redistribution. American Political Science Review, 79(2): 485-73. 
Ruddick, S. 1989. Maternal thinking. London: Verso.

Selden, S. C. 1997. The promise of representative bureaucracy: Diversity and responsiveness in a government agency. Armonk: M. E. Sharpe.

Shapiro, R. Y., \& Mahajan, H. 1986. Gender differences in policy preferences: A summary of trends from the 1996s to the 1980s. Public Opinion Quarterly, 50(1): 42-61.

Skocpol, T. 1995. Social policy in the United States: Future possibilities in historical perspective. Princeton: Princeton University Press.

Stone, D. 2002. Policy paradox: The art of political decision making (revised ed.). New York: Norton.

Swers, M. L. 1998. Are congresswomen more likely to vote for women's issue bills than their male colleagues? Legislative Studies Quarterly, 23(3): 435-48.

2005. Connecting descriptive and substantive representation: An analysis of sex differences in cosponsorship activity. Legislative Studies Quarterly, 30(3): 407-33.

Tilly, L. A., \& Gurin, P. 1990. Introduction: Issues and controversies in women's politics. In L. A. Tilly \& P. Gurin (eds.), Women, politics, and change (pp. 3-32). New York: Russell Sage Foundation.

True, J. 2003. Mainstreaming gender in global public policy. International Feminist Journal of Politics, 5(3): 368-96.

Tweedie, J. 1994. Resources rather than needs: A state-centered model of welfare policymaking. American Journal of Political Science, 38(4): 651-72.

United Nations. 2007. World population prospects: The 2006 revision highlights. New York: Author.

Walby, S. 2005. Gender mainstreaming: Productive tensions in theory and practice. Social Politics, 12(3): 321-43. 


\section{APPENDIX: DESCRIPTIVE STATISTICS}

\begin{tabular}{|c|c|c|c|c|}
\hline Variable & Mean & S.D. & M inimum & Maximum \\
\hline \multicolumn{5}{|l|}{ Childbirth support } \\
\hline First child & 105.87 & 195.35 & 0.00 & $1,000.00$ \\
\hline Second child & 225.35 & 328.21 & 0.00 & $2,000.00$ \\
\hline Third child & 285.95 & 837.38 & 0.00 & $5,000.00$ \\
\hline Fourth child & 559.00 & 896.71 & 0.00 & $5,000.00$ \\
\hline Fifth child & 593.78 & $1,044.46$ & 0.00 & $5,300.00$ \\
\hline \multicolumn{5}{|l|}{ Child-care support } \\
\hline First child & 60.52 & 375.43 & 0.00 & $4,200.00$ \\
\hline Second child & 133.04 & 681.79 & 0.00 & $6,000.00$ \\
\hline Third child & $1,002.90$ & $2,675.23$ & 0.00 & $14,400.00$ \\
\hline Fourth child & 935.08 & $2,644.22$ & 0.00 & $14,400.00$ \\
\hline Fifth child & 941.55 & $2,652.58$ & 0.00 & $14,400.00$ \\
\hline Female seats & 14.79 & 7.07 & 0.00 & 46.15 \\
\hline Female constituency & 49.85 & 0.97 & 46.96 & 52.57 \\
\hline Electoral competition & 76.23 & 17.76 & 0.00 & 100.00 \\
\hline Citizen liberalism & 11.89 & 4.78 & 4.81 & 42.43 \\
\hline Population (In) & 11.81 & 1.00 & 9.22 & 13.88 \\
\hline Change in population & -0.82 & 11.04 & -18.55 & 63.91 \\
\hline Total fertility rate & 1.35 & 0.26 & 0.84 & 2.33 \\
\hline Birthrate & 9.18 & 2.22 & 5.50 & 16.50 \\
\hline Change in birthrate & -0.12 & 1.17 & -4.80 & 4.80 \\
\hline Elderly dependence & 21.55 & 12.15 & 5.68 & 50.49 \\
\hline Gross regional product (In) & 17.97 & 0.75 & 16.87 & 19.28 \\
\hline Fiscal capacity & 80.92 & 84.35 & 23.49 & 884.78 \\
\hline Companies (In) & 9.12 & 0.97 & 6.96 & 11.06 \\
\hline Welfare households (per 1,000 ) & 44.69 & 23.33 & 7.31 & 118.89 \\
\hline Rural & 0.32 & 0.47 & 0.00 & 1.00 \\
\hline Metropolitan & 0.30 & 0.46 & 0.00 & 1.00 \\
\hline
\end{tabular}

Note: $\mathrm{N}=230$ for all variables. 